\title{
INVESTIGACIÓN
}

\section{Assessment of the process of cottonseed oil bleaching in hexane}

\author{
By Ola A. Megahed
}

\author{
Fats and Oils Department, \\ National Research Centre, Cairo, Egypt.
}

\section{RESUMEN}

\section{Evaluación del proceso de decoloración del aceite de semilla de algodón en hexano.}

Este trabajo ha sido iniciado para evaluar la viabilidad de la decoloración del aceite de semilla de algodón en miscela como un paso de procesado siguiente a la refinación alcalina en miscela. La refinación alcalina de aceite de semilla de algodón en miscela tiene varias ventajas sobre las tecnologías de refinación convencionales con respecto a la calidad del aceite, pérdida de aceite y coste del proceso.

Por tanto, ha sido comparada la eficacia del proceso de decoloración de aceite de semilla de algodón sin solvente y en una relación volumétrica aceite:hexano 1:1. La decoloración en presencia de hexano se llevó a cabo a $25^{\circ} \mathrm{C}$ mientras que la decoloración convencional a $110^{\circ} \mathrm{C}$. Se utilizaron diferentes lotes de tierras decolorantes en cada una de las dos técnicas de decoloración y se determinaron los índices de color de los aceites antes y después de la decoloración. La eficacia del proceso ha sido evaluada de acuerdo con la capacidad de decoloración, las pérdidas de aceite en tierras agotadas, la velocidad de filtración del aceite de la tierra decolorante y la acidez del aceite decolorado así como su contenido en peróxido.

Los resultados fueron usados para predecir las ecuaciones de adsorción de Freundlich para los pigmentos de los aceites en ambos casos. Estas ecuaciones fueron utilizadas posteriormente para predecir el color de los aceites obtenidos por decoloración de los aceites refinados de grados diferentes. Los resultados han mostrado que la decoloración del aceite es más eficaz en presencia de solvente cuando el aceite inicial es de un grado aceptable, y la inversa es verdad para aceites de bajo grado. También, la posibilidad de oxidación del aceite es menor durante la decoloración en presencia de solvente. Por otro lado, la decoloración en miscela ha proporcionado otras dos ventajas adicionales sobre la decoloración convencional. La filtración de aceite de la tierra decolorante es más rápida en la decoloración en miscela y las pérdidas de aceite sobre las tierras agotadas es baja. Esto se reflejará en la economía del proceso global.

PALABRAS-CLAVE: Aceite - Decoloración - Hexano - Refinación en fase miscela - Semilla de algodón.

\section{SUMMARY}

Assessment of the process of cottonseed oil bleaching in hexane.

This work has been initiated to assess the feasibility of bleaching cottonseed oil in miscella as a processing step next to alkali refining in miscella. Alkali refining of cottonseed oil in miscella has several advantages over conventional refining technologies with respect to oil quality, oil losses and process cost.

Therefore, the process efficiency of the bleaching of cottonseed oil in presence of hexane (at a volumetric ratio of $1: 1$ ), has been studied and compared to that without solvent. The bleaching in presence of hexane was carried out at $25^{\circ} \mathrm{C}$ whereas that by conventional bleaching at $110^{\circ} \mathrm{C}$. Different clay loads were used in each of the two bleaching techniques and the colour indices of the oils before and after bleaching determined in each case. The process efficiency has been evaluated according to the decolourization capacity, the oil losses on spent earth, the filtration rate of the oil from the clay and the acidity of the bleached oil as well as its peroxide content.

The results were used to predict Freundlich adsorption equations for the oil pigments in both cases. These equations were then used to predict the colour of the oils obtained by bleaching of refined oils of different grades. The results have shown that oil decolourization is more efficient in presence of solvent when the starting oil is of an acceptable grade and the reverse is true for low grade oils. Also, the possibility of oil oxidation during bleaching is less in presence of solvent. Moreover, the bleaching in miscella has proved two other additional advantages over conventional bleaching. The filtration of oil from clay is much faster in miscella bleaching and the oil losses on spent earth is lower. This will be reflected on the overall process economy.

KEY-WORDS: Bleaching - Cottonseed - Hexane - Oil - Refining in miscella phase.

\section{INTRODUCTION}

Cottonseed oil is, by far, the major vegetable oil processed in Egypt. In recent years, the local oil industry was faced by the problem of producing off coloured cottonseed oils. These oils are resistant to be decolourized due to the presence of certain type of pigments which cannot be removed by conventional methods of refining and bleaching (fixed pigments). These pigments develop either during the stage of seed or oil storage or during oil processing. Development of such type of pigments during processing is highly accelerated at high temperatures ${ }^{(1-5)}$.

Pigment fixation may occur during the heating process necessary to evaporate the solvent from miscella ${ }^{(6)}$. Solvent evaporation from the miscella usually takes place in a number of stages whereby the temperature could be raised in the last stage to about $110^{\circ} \mathrm{C}$. At this temperature, cottonseed oil 
pigments undergo serious alteration whereby they change to unrefinable and unbleachable forms. If the refining is carried out in miscella after a partial recovery of its solvent at moderate temperatures, the possible fixation of the oil pigments could be avoided and oils of lighter colour can be produced.

Certain other advantages of miscella refining are also apparent from literature ${ }^{(7-10)}$. Cottonseed oil-solvent mixture is much less viscous than the original, oil which greatly improves the fluid flow characteristics. This means less heat requirements and less power for mixer and pumps. In addition, the specific gravity differential between soap and miscella makes centrifugal separation more effective which lowers the free oil content of the soapstock.

It is also possible to continue the next processing step ; oil bleaching, in miscella. In this case the solvent is not recovered from the oil-hexane mixture after fatty acid neutralization, washing and separation. In this case the bleaching process is carried out in miscella at room temperature and the solvent is evaporated after bleaching.

This study is proposed to assess the technical feasibility of carrying out the bleaching process in miscella and to investigate whether it is more or less advantageous as compared to conventional bleaching process.

\section{EXPERIMENTAL}

The experimental work has been planned to investigate the efficiency of the bleaching in miscella as compared to conventional bleaching. Since the bleaching efficiency is determined by several factors including the decolourization efficiency, the effect of bleaching on the acidity and peroxide content, the filtration rate of oil from earth and the percentage of oil retained on the bleaching earth, these factors were considered in the present study.

The efficiency of the bleaching process to decolourize the oil was estimated according to the reduction in the oil colour index achieved by bleaching using a unit weight of clay for each hundred weight units of oil. This equals $(R-C) / m$ where $R$ and $C$ refer to the colour indices of the refined and bleached oils respectively while $m$ refers to the clay load as a percentage of the oil weight. Therefore, a number of bleaching tests were made whereby the colour indices before and after bleaching using a certain clay load were measured.

The refined cottonseed oil used in the present work has been kindly supplied by Tanta Company for oil and soap, Tanta, Egypt. The clay used for bleaching was a factory grade imported from Sud Chemie Co., Germany (Tonsil clay FF).

The bleaching of cottonseed oil $(20 \mathrm{~g})$ was carried out in conical flask (100 ml capacity). The oil was heated to the desired temperature on a thermostatically temperature controlled hot plate unit combined with a magnetic stirrer for about $10 \mathrm{~min}$. The adsorbent was then added and stirred for another $10 \mathrm{~min}$. at the same temperature. The clay loads used were $0.5,1,1.5,2$ and $2.5 \mathrm{~g} / 100 \mathrm{~g}$ oil. The bleaching was carried out at two different temperatures being $100^{\circ} \mathrm{C}$ (for conventional bleaching) and $25^{\circ} \mathrm{C}$ (for bleaching in miscella). In case of bleaching in miscella, the oil was mixed with commercial hexane at a volumetric ratio of 1:1. The bleached oils were then filtrated from the clay. The oil bleached in miscella was subjected for distillation under reduced pressure to remove the solvent. The bleached oils were then tested for their colour indices $^{(11)}$.

The effect of bleaching in miscella on the filtration rate of oil from clay was studied using hundred gram oil and a clay at a load of $1.5 \%$ which is the normal load usually used in practice. The volume of the filtrate from the oil-clay mixture was recorded over different filtration periods for the conventional bleaching as well as for bleaching in miscella. In case of the filtrate from miscella bleaching, the filtrated oil was determined after solvent distillation. The quality of oil lost on the spent clay after filtration has been also determined.

The development of peroxides and free acids during the bleaching process has been also studied in this work. Therefore, the peroxide value (P.V) and acid value (A.V) of the oil before and after bleaching of the above samples ( $100 \mathrm{~g}$ and $1.5 \%$ clay) have been determined according to the Official and Tentative Method of Analysis(12).

\section{RESULTS AND DISCUSSION}

The results of this study were used to compare the efficiency of the bleaching process of refined cottonseed oil at room temperature $\left(\approx 25^{\circ} \mathrm{C}\right)$ in presence of a solvent (commercial hexane) to that of the conventional bleaching method at $110^{\circ} \mathrm{C}$. The efficiency of the process is controlled by several factors including the capacity to adsorb the colouring matters, the filtration rate of the oil from the oil-earth mixture and the percentage of oil lost on the spent earth. It is also determined by its effect on the development of peroxides and free acids during the bleaching process.

\subsection{Capacity to adsorb colouring matters in the oil}

The quantity of the colouring matters in the refined oil which is removed by adsorption during the bleaching process is determined as the difference between colouring matter content in the refined oil and in the bleached oil. The colour index of an oil is an indication for the quantity of colouring matters present in such oil. Therefore, the difference between the colour index of the refined oil, R and that of 


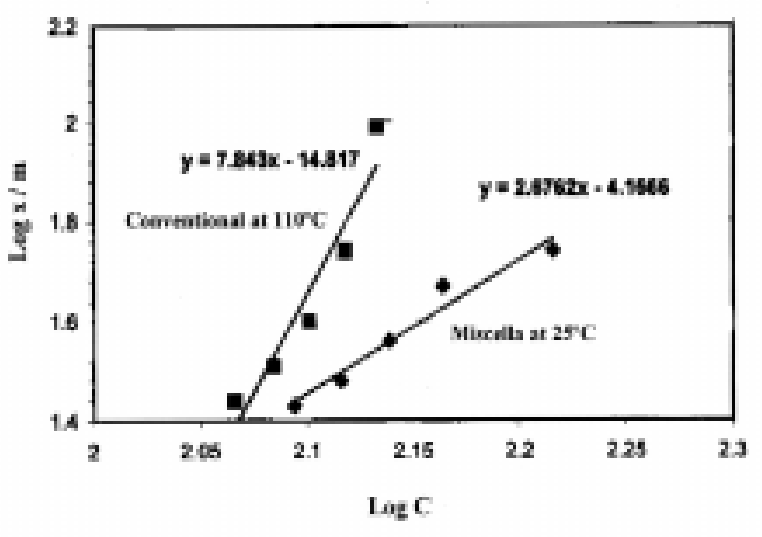

Figure 1

Adsorption isotherm of refined cottonseed oil using solvent and conventional method.

Table I

Exponent constants of cottonseed oil decolourization by solvent and conventional process

\begin{tabular}{lccc}
\hline \multicolumn{1}{c}{ Sample } & N & K & R \\
\hline Bleached with hexane $25^{\circ} \mathrm{C}$ & 2.676 & $6.813 \times 10^{-5}$ & 0.965 \\
Conventional method & 7.843 & $1.524 \times 10^{-15}$ & 0.948 \\
\hline
\end{tabular}

bleached oil, $\mathrm{C}$ can be taken as an indicator for the quantity of pigments removed by bleaching. The difference, R-C achieved per unit clay load, referred to as $x / m$ is plotted versus $C$ in Figure (1).

According to Freundlich's adsorption equation ${ }^{(4)}$ $\left(\mathrm{x} / \mathrm{m}=\mathrm{kc}^{\mathrm{n}}\right)$, the slope of the adsorption isotherm which fits the experimental results in Fig. 1 equals the exponent constant ; $n$, whereas the intercept of the isotherm with the ordinate equals the adsorption coefficient; $k$. The data were fitted in straight lines using the technique of regression analysis and the determined values of $\mathrm{k}$ and $\mathrm{n}$ are listed in Table $\mathrm{I}$.

Peroxide value of the refined cottonseed oil before bleaching equal $5.51 \mathrm{meq} / \mathrm{kg}$ Oil whereas the acid value of this oil was $0.43 \mathrm{mg} \mathrm{KOH} / \mathrm{g}$ Oil.

On the basis of derived Freundlich's adsorption equations for the removal of colouring matters from cottonseed oil, the loads of clay $(\mathrm{m})$ which is required to decolourize refined oils of colour indices 150, 200 and 250 to colour indices, c, between 70 to 170 were estimated and the results are graphically shown in Fig. 2-4. The estimations were made for the prementioned $R$ and $C$ values as these values cover the removal range for colour indices of regular refined as well as bleached oils. It can be understood that the bleaching in solvent was more suitable for good grades of refined oil which has low colour index less than 120.

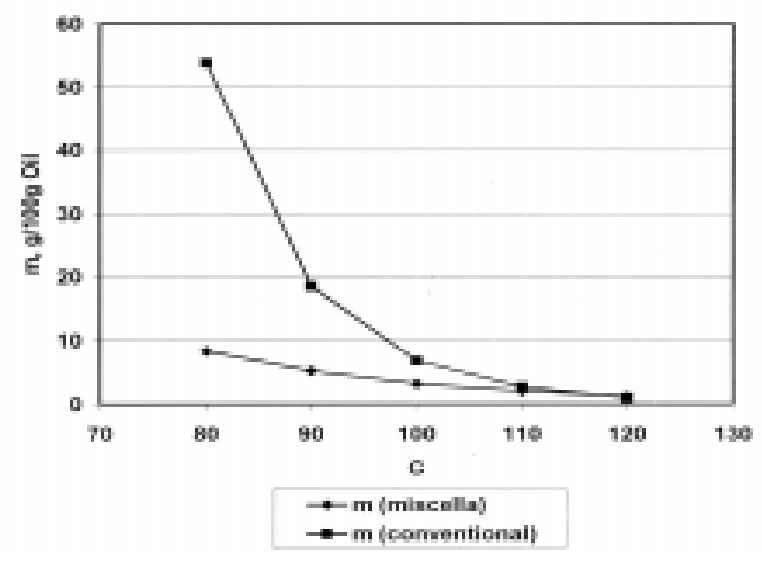

Figure 2

The load of clay required to decolourize refined cottonseed oil of colour index equal 150.

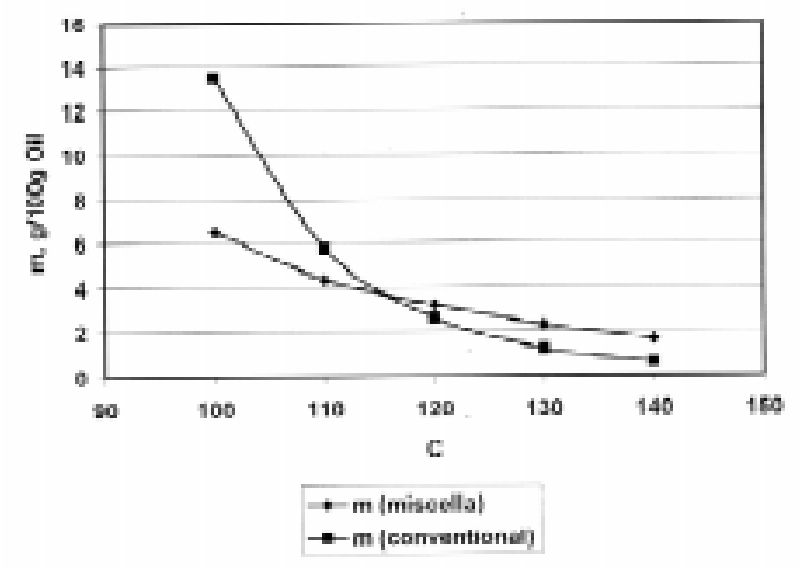

Figure 3

The load of clay required to decolourize refined cottonseed oil of colour index equal 200.

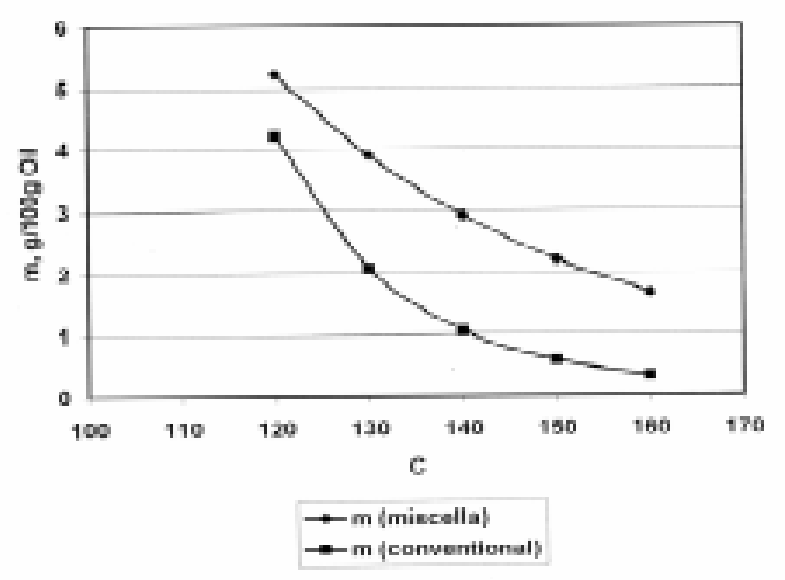

Figure 4

The load of clay required to decolourize refined cottonseed oil of colour index equal 250. 


\subsection{Effect of bleaching in miscella on the oil filtration rate}

In addition to the colour of the bleached oil, the efficiency of the bleaching process is also determined by the rate of oil filtration from the bleaching earth. Fast filtration of oil saves the overall process cost. The results shown in Fig. 5 indicates that the filtration of the oil from the bleaching earth occurs at a much faster rate when the bleaching is carried out in miscella. For example, the results of bench scale filtration tests carried in the present work have shown that the filtration of 12 gram oil is achieved within 12 minutes in case of miscella bleaching compared to 60 minutes in conventional bleaching. Thus, the filtration time of oil bleached by conventional method is almost five times that required in miscella bleaching.

\subsection{The effect of bleaching in miscella on the percentage oil lost on the spent earth}

In addition to the oil colour and the filtration rate, the losses of oil retained on the bleaching clay should be also considered in the evaluation of a certain bleaching process. The quantity of oil lost on the bleaching clay determined as a percentage of the clay load was found to be $40.6 \%$ in case of miscella bleaching compared to $58.6 \%$ in conventional bleaching. This means that a saving of a quantity of bleached oil equivalent to $18 \%$ of the load of clay used can be achieved if the process is carried out in miscella. This in turns, will be reflected on an overall increase in process income.

\subsection{Effect of bleaching in miscella on the development of peroxide and free acids during the processing}

Table II lists the peroxide values as well as the acid oils after bleaching in miscella and after bleaching by

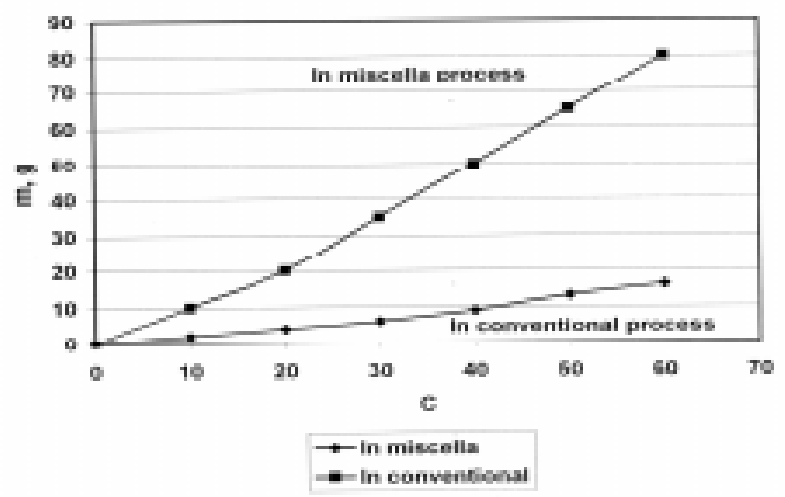

Figure 5

Effect of bleaching in miscella and conventional process on the oil filtration rate.
Table II

The peroxide and acid values of the oil heated for one hour in presence and absence of clay

\begin{tabular}{lcc}
\hline Bleached sample with $1.5 \%$ clay & $\begin{array}{c}\text { P.V, meq/kg } \\
\text { Oil }\end{array}$ & $\begin{array}{c}\text { A.V, mg KOH } / \mathrm{g} \\
\text { Oil }\end{array}$ \\
\hline In miscella process at $25^{\circ} \mathrm{C}$ & 5.01 & 0.26 \\
In conventional process at $110^{\circ} \mathrm{C}$ & 7.06 & 0.74 \\
\hline
\end{tabular}

where P.V = Peroxide value of the cottonseed oil

A.V = Acid value of the cottonseed oil

Refined oil without clay at $110^{\circ} \mathrm{C}$ (control) for one hour has $P . V=9.51 \mathrm{meq} / \mathrm{kg}$ Oil and A.V $=0.32 \mathrm{mgKOH} / \mathrm{g}$ Oil.

methods at $100^{\circ} \mathrm{C}$ for one hour. This table includes also the acid value of the refined oil heated for the same period temperature in absence of clay (control).

The results show that the peroxide value of the oil have been changed from 5.51 in case of the original refined oil to 9.51 after the oil has been heated for one hour at $110^{\circ} \mathrm{C}$ in absence of clay compared to 7.06 by conventional bleaching. This means that the net increase in the peroxide value was 4.0 and 1.55 in absence and in presence of the clay respectively. This can be attributed to the catalytic effect of the clay on the decomposition of the oil peroxides.

On the other hand, the bleaching in miscella have been shown a slight effect only on the peroxide value of the oil. This means that the rate of oil oxidation when the bleaching process is carried in miscella was values of the conventional peroxide and at the same in general low compared to conventional bleaching. This is expected since the bleaching process is carried at lower temp (room temp) and because the oil is diluted in the solvent.

Regarding to the bleaching effect on the oil acidity, the obtained results show insignificant effect of bleaching whether in miscella or by conventional method on the oil acidity.

\section{CONCLUSIONS}

According to the achieved results in this study, it can be concluded that the bleaching of oils in miscella reduces the quantity of oil losses and improves the filtration rate from the earth. In addition, the bleaching in miscella at room temperature saves the energy consumed in the process. However the adsorption of colouring matters at room temperature was less efficient than conventional at $110^{\circ} \mathrm{C}$. Therefore, this technology can be recommended in case of refined vegetable oils which not very dark coloured such as sunflower and soybean oil.

\section{REFERENCES}

1. Atteia, M., Abbasy, M., El-Nockrashy, A.S. and Shoeb Z.E. (1981). Cottonseed colour fixed pigments. Part III. 
Prevention of colour fixation and removal of colour-fixed pigments. Die Nahrung, 25, 608-615.

2. El-Nockrashy, A.S., Zaher, F.A. and Osman, F. (1976). Cottonseed colour fixed pigments. Part 1. Selectivity of hexane isomers. Die Nahrung, 20, 117-121.

3. Helmy, H.E., Ph.D. (1985). Thesis, Fac. of Agric., Am Shams Univ., Cairo, Egypt.

4. Gutfinger, T. and Letan, A. (1978). Pretreatment of soybean oil for physical refining: Evaluation of efficiency of various adsorbents in removing phospholipids and pigments. J. Am. Oil Chem. Soc. 55, 856-859.

5. Megahed, O.A., B. Sc. (1991). Thesis, Fac. Of Eng. Cairo University, Egypt.

6. El-Nomany, H.M. and Zaher, F.A. (1987). Cottonseed oil pigment content as affected by miscella refining and oil storage. Seifen Ole Fette Wachse. 113, 74-75.

7. Toro-Vazquez, J.F., Mendez-Montealvo, G. and Chavo-Alonso, M.A. (2000). Adsorption efficiency of selected adsorbents in sesame oil miscellas. Journal of Food Lipids 7, 151-162.
8. Kun-She Low, Choong-Kheng Lee, and Lee-Yong-Kong. (1998). Decolorisation of crude palm oil by acid-activated spent bleaching earth. Journal of Chemical Technology and Biotechnology 72, 57-73.

9. Loft-S. (1998). Minimizing oil loss in miscella refining. Oil-Mill-Gazetteer 103, 26,28-30.

10. Collaborative studies of the german fat science association. (1995). Bleaching of edible fats and oils. Fette Wissenschaft-Technol. 97, 177-182.

11. Pons, W.A., Jr., Kuck, J.C. and Frampton, V.L. (1960). Colour index for cottonseed oils". J. Am. Oil Chem. Soc. 37, 671.

12. AOAC. (1995). Official and Tentative Method of Analysis, (2nd ev. Rev. to) Am. Oil. Chem. Soc. Chicago. 